\title{
Foreign Direct Investment Led Growth Hypothesis and Economic Development in Nigeria
}

DOI: https://doi.org/10.47175/rissj.v2i4.320

\author{
| Ubong Edem Effiong ${ }^{{ }^{*}}$ \\ ${ }^{1,2}$ Department of Economics, \\ University of Uyo, P.M.B. 1017, \\ Uyo, Akwa Ibom State, Nigeria \\ *ubongeffiong3@gmail.com
}

\begin{abstract}
Nora Francis Inyang ${ }^{2}$ |

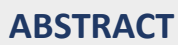

This study was an inquiry into the nexus of the foreign-direct investment (FDI) led growth hypothesis, and how it translates into the development of the Nigerian economy as of $1970-2018$. The study utilized secondary data from the 'World Development Indicators' which were analysed using the Bounds test for cointegration and the 'autoregressive distributed lag (ARDL) approach to divulge both the short-term cum the long-term influence of foreign direct investment net inflow on 'economic development' of Nigeria. The Bounds test was conducted after the unit root test revealed that the variables were stationary at mixed order of level and first difference. The outcome of the ARDL Bounds test supported confirmation of long-term association among the variables. The ARDL short-run error correction showed that $14.62 \%$ of the instability in the model was corrected yearly. In the short-term, it was discovered that FDI wielded a deleterious and substantial weight on 'economic development of Nigeria. Meanwhile, the long-term estimates indicated that FDI influenced economic development positively, though not in a significant manner. The Granger causality test supported the fact that FDI causes 'economic development' in Nigeria. Given this potential of FDI exerting a positive effect on 'economic development', the paper recommended that bottlenecks inherent in FDI influxes in the country should be removed so as to reap the fullest benefits of such inflows in Nigeria.

KEYWORDS

economic development; FDI; economic growth; ECM.
\end{abstract}

\section{INTRODUCTION}

The connection amid FDI and 'economic development' of a nation can be traced to the 'neoclassical theory'. In line with this theory, both labour and capital are considered as the potent factors that can drive 'economic growth' of a nation. Neoclassical trade theories universally supported international trade even when a country had an 'absolute advantage' in all 'economic growth' variables (Olorogun, 2021). It follows from this that the neoclassicals set the groundwork for globalization, which is the foundation of the FDI-led growth concept. Thus, the recent large surge in capital influxes across global markets can be attributed to a constant growth in financial transactions between countries (Giwa, George, Okodua, and Adediran, 2020). Furthermore, a key element underpinning this experience has been the growing internationalization of investors wanting greater yield on investment per time and the ability to spread risk worldwide (Giwa, George, and Okodua, 2019).

Rani and Kumar (2019) had asserted that the current design of 'internationalization' and 'globalization' is visible in the transfer of technology and human resources to accompany or help local companies in producing the desired 'economic development'. They 
discovered that trade openness stimulates economic growth in high-productivity areas, resulting in economic development in the 'BRICS' (Brazil, Russia, India, China, and South Africa) countries.

Studies has clearly defined the benefits of globalization in a 'developing economy'. The host country benefits greatly from unrestricted capital movement (Schmitt and Alexiou, 2016). Among these benefits are the establishment of Employment opportunities, knowledge transfer, economic development. This reinforces the FDI-led growth thesis, which is undoubtedly one of the reasons governments throughout the world try to create and execute investment-oriented economic and political policies to attract FDI inflows (Olorogun, 2021). Meanwhile, FDI inflows are determined by diverse factors. These include a wealth of natural resources, modern infrastructure, a standardized system, and an enough supply of inexpensive and skilled labour (Papageorgiadis, McDonald, Wang and Konara, 2020).

Given the fact that the inflow of FDI are determined by factors as divulged by Papageorgiadis, et al. (2020), it bring about that governance (standardized system) can be a key driver of FDI inflows in a nation. Most West African countries' governance indices has indicated negative values over time. This is depicted in the table below.

Table 1. Average Governance Indices in Selected West African Countries, 2002 - 2019.

\begin{tabular}{|c|c|c|c|c|c|c|}
\hline Country & 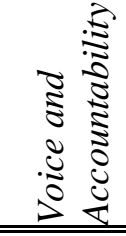 & 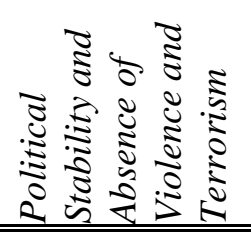 & 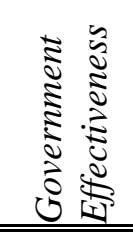 & 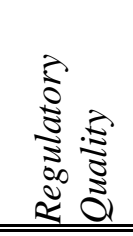 & $\begin{array}{r}0 \\
0 \\
0 \\
0 \\
0 \\
0 \\
0 \\
0 \\
0 \\
0 \\
0\end{array}$ & 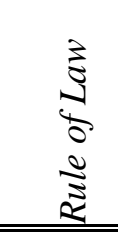 \\
\hline Benin Republic & 0.231 & 0.263 & -0.517 & -0.448 & -0.586 & -0.554 \\
\hline Burkina Faso & -0.249 & -0.401 & -0.612 & -0.274 & -0.254 & -0.443 \\
\hline Ghana & 0.423 & 0.017 & -0.103 & -0.080 & -0.137 & 0.026 \\
\hline Guinea Republic & -1.044 & -1.259 & -1.063 & -1.004 & -1.027 & -1.321 \\
\hline Gambia & -0.911 & 0.064 & -0.658 & -0.443 & -0.606 & -0.463 \\
\hline Liberia & -0.386 & -0.921 & -1.332 & -1.202 & -0.814 & -1.081 \\
\hline Mali & -0.005 & -0.763 & -0.842 & -0.492 & -0.645 & -0.482 \\
\hline Nigeria & -0.572 & -1.936 & -1.036 & -0.881 & -1.144 & -1.123 \\
\hline Senegal & 0.089 & -0.168 & -0.332 & -0.204 & -0.193 & -0.186 \\
\hline Togo & -0.949 & -0.408 & -1.312 & -0.817 & -0.892 & -0.853 \\
\hline
\end{tabular}

Source: Author Computation from World Governance Indicators.

Since Nigeria is our core point of concern, the indices indicated that all the governance indices for the country were negative from $2002-2019$. Could this affect to the net FDI inflows in the country? An insight into data can provide a succinct result. The net FDI inflow of Nigeria has exhibited high degree of instability over time. Such trend is depicted in Figure 1.1, where we observed high degree of gyrations in the variable. Between 1970 to 1981, FDI net inflow as a proportion of 'GDP' in Nigeria exhibited a continuous decline, reaching even a negative value $(-1.15 \%)$ as at 1980 . Thereof, a minute improvement was observed with high volatilities from 1982 to 1984 . Within the period, the value averaged $1.91 \%$, with a record high of $2.45 \%$ as at 1984 . 


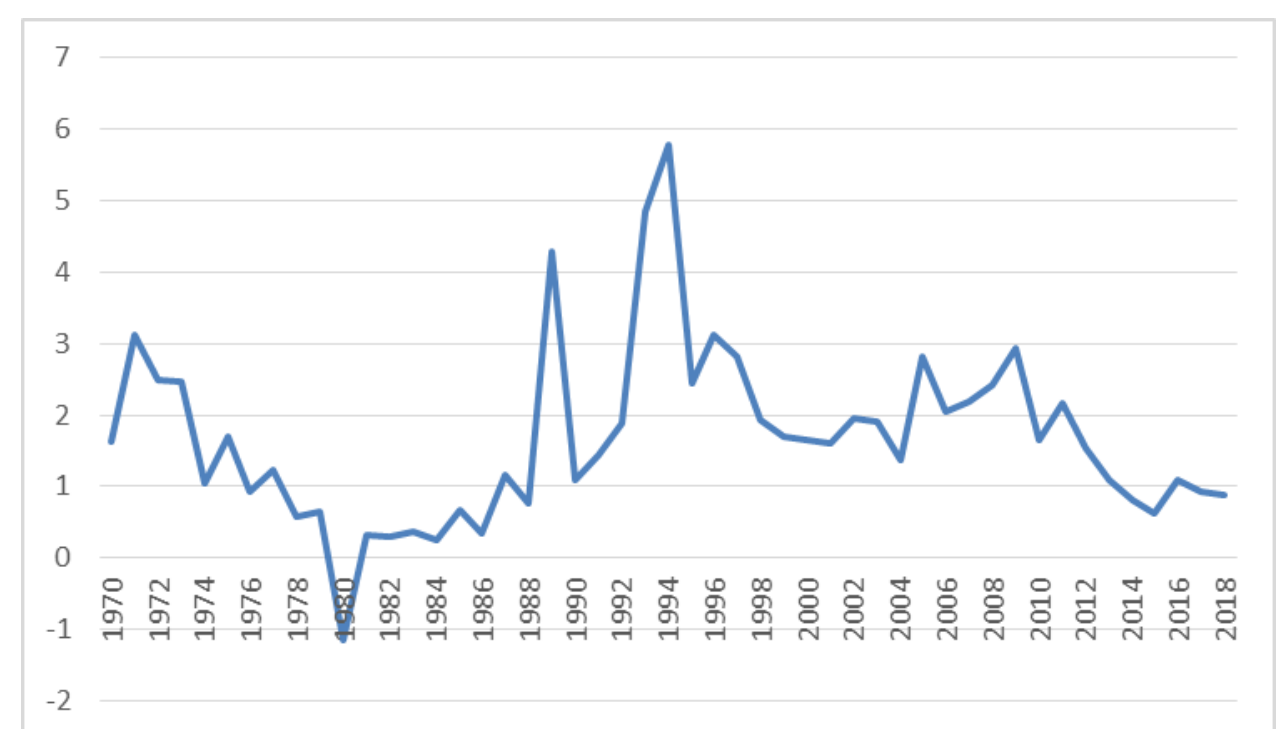

Figure 1. Trend in FDI Net Inflows as a Percentage of GDP in Nigeria (1970 - 2018)

Thereafter, the value declines continuously to as low as $1.08 \%$ as at 2013 ; and then to a meagre $0.87 \%$ as at 2018 . In this same period, the behaviour of the growth rate of per capita GDP was also in an oscillating matter. Such is depicted in Figure 2.

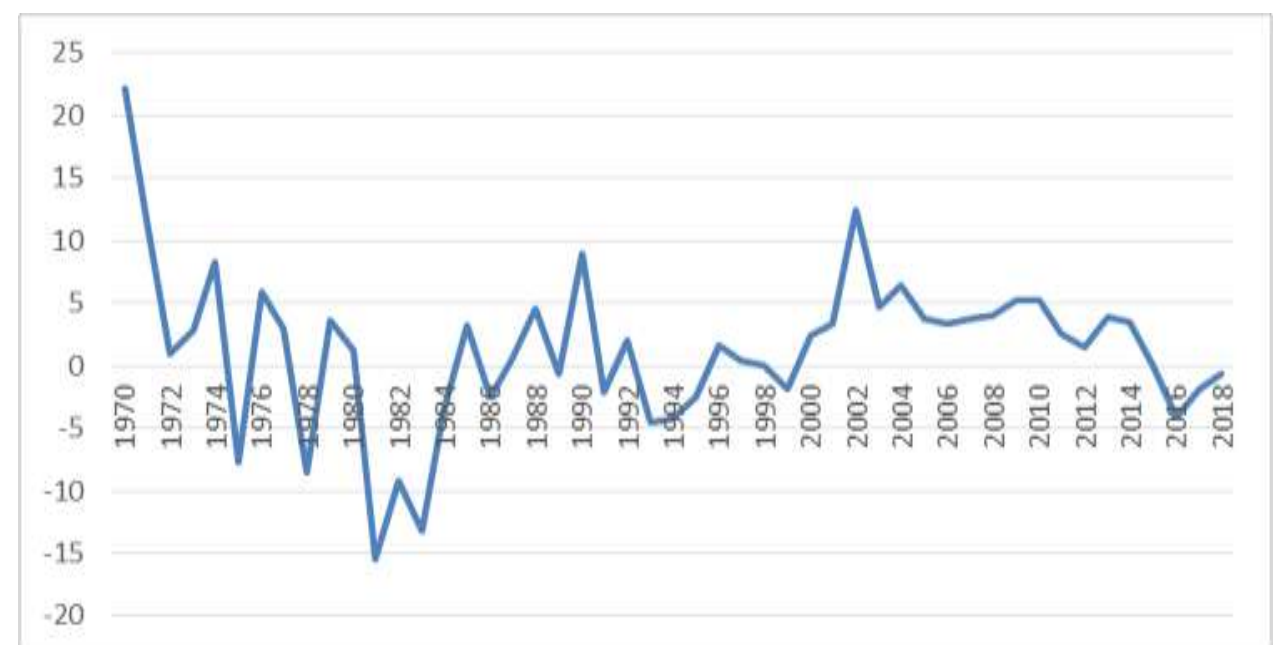

Figure 2. Trend in Per Capita GDP Growth Rates in Nigeria (1970 - 2018)

As depicted in Figure 2, a drastic decline in the per capita growth rate of GDP was witnessed right from 1970, where the value of the variable declined from $22.18 \%$ in 1970 to $0.95 \%$ in 1972 . This was followed by a negative growth rate of $-7.77 \%$ as at 1975 . Improvements was observed between 1976 and 1977 until the value returned negative as at 1978, where the value was put at $-8.58 \%$. Thereafter, the period 1979 and 1980 experienced positive growth rates in the variable of interest. In the early 1980s, (1981 to 1984), the economy experienced a negative growth rates in GDP per capita for four consecutive years. This portrayed a low standard of living and economic misfortune of the country as at then. This led to the introduction of 'Structural Adjustment Programme' (SAP) in the country as at 1986 . This was followed by periods of positive and negative growth rates in the variable from 1986 till 1999. With full democratic dispensation in the country (2000 to 2014), the growth rate in the variable exhibited positive values over the time horizon, averaging 4.39\%. Subsequently, the value remained negative from 2015 - 
2016, averaging $-1.66 \%$. One could therefore wonder whether these fluctuations in the FDI's net inflows to the country could have a distinct effect on the development of Nigeria. there were multifarious outcomes on the effect of FDI on 'economic growth' and 'development' of a nation. Researchers such as Akinboade, Siebrits and Roussot (2006) and Sunde (2017); Joshua (2019) and Olorogun, Salami and Bekun (2020); and Asamoah, Adjasiand and Alhassan (2016), Anarfo, Agoba and Abebreseh (2017) and Olorogun (2021) investigated the connection amid FDI and economic expansion in South Africa, Nigeria, and Ghana correspondingly. Their findings confirmed FDI as a motivating force in 'economic growth', with Joshua (2019) discovering a long-term connection stuck amid FDI and economic expansion.

Similarly, Joshua, Adedoyin and Sarkodie, (2020) and Joshua, Bekun, and Sarkodie (2020) used the Toda and Yamamoto causality test to explore whether FDI-led economic development in South Africa is causative. Their findings demonstrated that FDI inflows are critical to South Africa's economic growth. Nonetheless, series of previous studies have found a nonexistence of bond amid FDI inflows and economic development. Khobai, Hamman, Mkhombo, Mhaka, Mavikela and Phiri (2017), Zandile and Phiri (2019), Joshua and Alola (2020), Sarkodie and Adams (2018), and Udi, Bekun, and Adedoyin (2020) established no rapport amid FDI inflows and 'economic development' across African countries. This calls into doubt the worth of FDI-led growth in Nigeria.

This study is therefore aimed at ascertaining the effect of 'foreign direct investment' on 'economic development' of Nigeria. The specific objectives are:

i. To investigate the effect of net foreign direct investment inflows on economic development of Nigeria.

ii. To ascertain the nature of the bond amid net foreign direct investment inflows and economic development in Nigeria.

Paper's structure is as follows we portray it in five core sections. Immediately after this introduction is the literature review in section 2. In section three, the methodology of the research is portrayed; while section four reflects the empirical findings. Finally, section five conveys the conclusion and recommendations of the study.

\section{LITERATURE REVIEW}

\section{Theoretical Literature}

Theories on foreign direct investment (FDI) as it promotes growth can be viewed from diverse perspectives.

\section{Classical Theory}

The classicalists identified various channels through which foreign capital inflows and deeds of the conglomerates can stimulates development in the host country. Such channels include capital transfer, balance of payments enhancements, enlargement of tax base along with foreign exchange earnings, cutting-edge technological equipment and skills, job creation and assimilation of host country into global marketplaces (Aminu, 2020). Muchlinski (1995) and Umar (1980) cited in Aminu (2020) has noted that this view has been noted in most industrialized countries' growth like Taiwan, South Korea, Hong Kong and Singapore during 1980s and early 1990s. This has also been linked to China's 'economic growth' of recent.

\section{Dependency Theory}

The dependency theory is linked to the experience of the Latin America. Based on the theory, Wilham and Witter (1998) cited in Aminu (2020) pointed out that advocates of this 
theory are of the opinion that free trade relations and foreign investment with the highly industrialized nations are the core causes of underdevelopment and exploitation of 'less developed countries'. The core concern of the theory is between the centre (comprising the highly industrialised nations) and the periphery (consisting of 'less developed countries'). Based on this, FDI is considered as the channel through which the centre exploits the periphery and prolongs the latter's condition of 'underdevelopment' and reliance. Somarazah (1994) cited in Aminu (2020) opined that FDI strangles development and propagates the dominance of fragile countries, rather than stimulating 'economic development'. It follows from this view that multinationals are considered as exploiters of the fragile nations since they are habitually involved in natural resources exploitation with no parallel remunerations for host country (UNCTAD, 1999).

\section{Middle Path Theory}

Another theory is the 'Middle Path Theory' which is a merging of laissez-faire of Adam Smith and government intervention by J. M. Keynes. The theory states that FDI has to be protected up to only the extent of the beneficial role it plays to the host economy and the degree to which those investors acts as good corporate citizens in propelling economic and social goals of the host economy (Aminu, 2020 cited in Aminu, 2020). Seid (2002) cited in Aminu (2020) stated that this theory advocates for 'intervention and openness' in dealing with foreign investors and cautions against excessive guideline or interference. The theory advocates for a balance in the act which can be conducted by the market and those that can be effected by the government.

\section{Direct Input Theory}

In this theory, output (Y) is directly connected to the fundamental inputs of capital $(\mathrm{K})$ and labour (L). This may be map out back to Solow's (1956) prominent seminar paper, which functioned as the groundwork for copious research that utilized growth analysis under the neoclassical framework. Accordingly, the two equations underneath recapitulate the role of investment.

$Y_{\mathrm{t}}=A \cdot f(K, L)-\cdots-\cdots-\cdots(2.1)$

$\Delta K_{\mathrm{t}}=I_{\mathrm{t}}-\delta K_{\mathrm{t}-1}-\cdots-\cdots-\cdots(2.2)$

Equation (2.1) denotes a 'production function' that depicts the association amid output (Y) along with the aforementioned inputs, and technical development (A), whereas Equation (2.2) denotes 'accumulation of capital'. This defined the association amid tangible 'asset investment' (I) cum 'capital stock' (K).

The aforementioned neoclassical model's consistency and theoretical foundation on $\Delta K_{t}$ and 'economic growth' are important and appropriate for use in this research. Nonetheless, the major flaw in this theory is that $\Delta K_{\mathrm{t}}$ is susceptible to decreasing returns, and hence continuous growth cannot be realized in the 'absence' of external technological development (Giwa, George, Okodua, and Adediran, 2020).

\section{The New Growth Theory}

In line with This theory, a much less advanced united states that assures excessive savings (investment), that is capital accumulation, and stays to surge the saving rate would attain a significantly grander level of production. Likewise, Solow (1956) applied the theory by arguing that the permanent growth rate of output per unit of labour input is selfdetermining of the savings rate, which is investment, and is heavily influenced by the pace of technical development. Accordingly, this growth paradigm relies principally on the 
production and diffusion of technological knowledge. This focuses on innovation, invention and creativity principal stimulants of a country's economic success. The model, conferring to Lucas (1988) and Grossman and Helpan (1991), assumes "Constant diminishing returns and state of technical progress" (Giwa, George, Okodua, and Adediran, 2020).

Arrow (1962) argued, in support of Solow (1956) And other theorists of "new growth" investing in tangible assets inevitably create spill over since technology is an unswerving consequence of capital. This was supported more by Romer (1986), who asserted that high-tech advancement is determined by the stock of R\&D. He also advocated in support of more knowledge investment to produce natural spill overs. Furthermore, literature has confirmed that FDI influx is reliant on on $R \& D$, consequently when a country has superior access to all factor inputs handy in more fortunate economies, such economy would enjoy higher productivity (Lucas, 1988). Nevertheless, in contrast to the older neoclassical paradigm, the 'new growth theory' describes technological development as a type of investment spill over from many sources. As a result, it can be further said that FDI can have a direct influence About growth and indirect impact on local investment. However, the magnitude of the impact is primarily determined by the amount of the spill over (Giwa et al., 2020).

\section{Positive Spill Over Theory}

Hymer's (1976) seminar research presented external differences among businesses at both scientific and technical levels as a basis of technological spill overs and transfer, which tantamount to the development of models of FDI and spill over benefits. On one side, the study defined FDI as a global extension of 'industrial organization' theory. Wang and Blomstrom (1992), on the other side, indicate that technological diffusion is auspiciously and markedly Coupled with indigenous efficiency businesses and their degree of operational risk. Similarly, Blomstrom and Kokko (1998) proposed that spill over occurs when international businesses enter or are present and bring about output efficiency of indigenous firms. Giwa et al. (2020) focused on four primary pathways of technology spill overs from multinational businesses to indigenous enterprises in the host country. The channels are:

i. Observational learning that occurs when domestic companies increase their capacity by imitating the technologies used by international companies, especially in the face of competition (Jenkins, 1990; Wang and Blomstrom, 1992);

ii. Competition: When the presence of multinationals in the local economy creates competition between locals, each local is encouraged to adopt new technologies from industry-leading multinationals to maintain relevance. Will be (Kokko, 1996). Here, there is a risk that local companies will have to compete with international companies and in some cases be kicked out of the market.;

iii. Labor transfer: FDI facilitates interconnection by bringing technical know-how and skills to host countries. This is made possible through the training of workers and the dissemination of good management and organizational practices. The transfer of information from an international company to a local company automatically transfers the knowledge to the local company (Fosfuri, Motta and Ronde, 2001; Glass and Saggi, 2002);

iv. NS. Links: There are two forms of FDI spillover over links. The first multinationals operating in the same industry can have a productivity impact on indigenous peoples (horizontal spillover), then multinationals are productive on indigenous 
peoples in downstream areas. It can affect you. Has upstream industry (forward and backward) links.

\section{Empirical Literature}

Studies have portrayed NS. Left: There are two forms of FDI left spillover. The first multinational companies to do business in the same industry can have a productivity impact on indigenous peoples (horizontal spillover), and multinational companies bring productivity to indigenous peoples in downstream areas. It can affect you. There is a connection with upstream industries (forward and backward).

The undesirable influence of 'FDI' on 'productivity' of indigenous firms observed by Aitken and Harrison (1999) portrays that indigenous businesses are endangered and the 'macroeconomic' atmosphere of the local economy is frail. The finding has a preference to the 'market-stealing' hypothesis. Based on the hypothesis, when FDI support technical transmission, peripheral investors may control the market stake and produce at economical per unit costs, whilst indigenous firms produce lesser output at greater overheads. Such opens the indigenous businesses to harmful competition with periphery. Consequently, the primary aims of enticing FDI by 'the centre' may not be realised (Giwa et al., 2020).

The interconnection amid FDI and output growth was examined by Senbenta (2008) for 22 sub-Saharan African economies within 1970 and 2000. The study utilized the "Fixed effect" and "Dynamic panel model". The outcome of the study indicated a negative shortrun effect of FDI on output growth whilst, the effect was a positive one in the long-term. De Mello (1999) is of the view that the favourable effect of FDI on growth is reliant on 'the level of substitution and complementarity between FDI and local investment' while Malikane and Chitambara (2017) saw it as being reliant on sector, along with the economic circumstance of the home economy. In this regards, Roy (2009) pointed out that 'the remoteness to the expertise boundary is central in defining the aptitude of the centre to gain from externalities inherent in FDI'. Similarly, Alfaro et al. (2009) in their study indicated that nations with strong financial system are most likely to benefit to a large extent from FDI via increase in output.

Iamsiraroj and Doucouliagos (2015) used a 'meta-regression' approach to highlight a desirable bond amid 'growth' and 'FDI', which was shown to be stronger in country specific studies than in inter-country studies. As a result, Leito and Rasekhi (2013) used 'fixed-effects' and 'random-effects' models to investigate the consequence of 'FDI' on real 'GDP' per capita in respect to Portugal starting from 1995 to 2008, and discovered that FDI stimulates progression. Mahapatra and Patra (2014) claimed that FDI plays a vital part in India's economic progression. Chan, Hou, Li, and Mountain (2014) established that FDI has a substantial desirable influence on GDP both in the short and long-term, using Chinese provincial panel data. Saini, Madan and Batra (2015) looked at the 'South Asian Association for Regional Cooperation' (SAARC), finding that FDI has a desirable influence on GDP, gross national income, and export growth, but has an undesirable influence on financial position and trade openness. Mahadika, Kalayci, and Altun (2017) used a VAR model to show the presence of a long-term bond amid GDP, FDI, and export volume in Indonesia.

Alshamsi, Rasid bin Hussin, and Azam (2015) used ARDL model for the United Arab Emirates and found a strong desirable bond amid GDP per capita and FDI. Sunde (2017) established unidirectional causation between FDI and economic development in South Africa. Kinuthia and Murshed (2015) pointed out that in Kenya, economic development drives FDI expansion, but in Malaysia, amplified FDI influxes Granger-causes economic progression. 
Akinlo (2004), on the other hand, demonstrated for Nigeria that FDI favourably influences growth, but only after a considerable break and is not substantial. In a similar vein, Abdallah and Abdullahi (2013) used the VEC model as a technique of estimate for Nigeria from 1980 to 2009 and discovered zero causal link between FDI and growth in the short-term, but an undesirable bond in the long-term. Furthermore, Yalta (2013) discovered that there is no substantial bond amid FDI and economic progression in China. Temiz and Gokmen (2014) demonstrated the absence of a substantial link amid FDI and economic development in Turkey from 1992 to 2007. Carbonell and Werner (2018) confirmed that FDI is not a growth driver in Spain.

Using panel regression analysis, Gherghina, Simionescu, and Hudea (2019) explored the connection amid FDI influxes and 'economic development' for eleven Central and Eastern European nations as of 2003 to 2016. The actual findings backed up the theory of a nonlinear connection amid FDI and GDP. The panel VECM and Granger causality test support a one-way connection bond amid FDI and growth in the short-run and a two-way connection bond amid FDI and growth in the long-term.

Furthermore, cross-country studies, according to Herzer et al. (2008), showed that FDI exercises an advantageous influence in boosting economic progression. Ndiaye and $\mathrm{Xu}$ (2016) looked at seven nations in the WAEMU and It turns out that "FDI" has had a beneficial effect on "growth." Ketteni and Kottaridi (2019) discovered the positive impact of "FDI" on "growth."' for 35 emerging and 31 'developed' countries, with an increasing benefit as the percentage of FDI inside the state grows. Schneider (2005), on the other hand, found that, except for 'developed countries', FDI had no significant association with economic development for 47 'developed' and 'developing' countries as of 1970 to 1990. In addition, Herzer et al. (2008) found that FDI had no long-term or short-term influence on growth in 28 developing countries. Furthermore, Dutta and Roy (2011) demonstrated that the bond amid financial development and FDI influxes is non-linear, comparable to Kottaridi and Stengos (2010), who verified that 'FDI inflows' and 'growth' have a 'nonlinear relationship'.

Giwa, George, Okodua, and Adediran (2020) carried out a study to investigate how inflows of FDI can affect the Nigeria's Real GDP using the 'robust GMM' technique of estimation. Findings from the analysis portrayed that the influence of labour quality is desirable and substantial; while the effect of capital concentration was adverse and substantial on RGDP. The result portrayed no better connection between FDI and capital concentration as they move the economy in a progressive manner. Intensified efforts geared towards attracting FDI inflows to the productive sectors was recommended by the study.

Finally, Olorogun (2021) investigated a novel model for the Rwandan economy that describes the FDI-led growth hypothesis. The Johansen cointegration and ARDL methods were employed. Except for financial development from the banking sector, that was substantial in the short-run but negligible in the long-term, other factors were shown to have a favourable influence on economic development. The long-term result portrayed that financial development wields a deleterious and substantial influence on FDI in Rwanda; while GDP and population generated a positive and significant effect.

\section{RESEARCH METHODS}

\section{Research Design}

This study utilizes the econometric approach to examine how foreign direct investment could influence the pace of development within the Nigerian context. The study utilizes secondary data from 'World Development Indicators' that is confined within 1970 to 2018 
- a total of forty-nine (49) years. This period of study covers key regimes in the polity (both military and civilian) as well as incorporating key periods of economic shocks booms and recessions.

\section{Model Specification}

Economic development in defined by the per capita gross domestic product. This measurement is valid in the sense that it portrays the standard of living of the society. Meanwhile, foreign direct investment is captured as a ratio of the gross domestic product. This relationship between 'foreign direct investment' inflow and 'economic development' is expressed as follows:

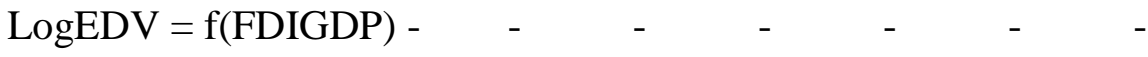

Where:

$\mathrm{EDV}=$ Economic development, and

FDIGDP $=$ Foreign direct investment as a proportion of GDP. Incorporating some control variables, Equation (3.1) becomes

$\operatorname{LogEDV}=\mathrm{f}(\mathrm{BMGDP}$, FDIGDP, INFL, POPG, EXCR, TRPN $) \quad-$

Where:

BMGDP $=$ Broad money supply as a proportion of GDP (a measure of financial depth)

INFL = Inflation rate

POPG = Population growth rate

EXCR = Exchange rate

TRPN = Trade Openness

Equation (3.2) is expressed in an econometric form as follows

$\operatorname{LogEDV}=\omega_{0}+\omega_{1} B M G D P+\omega_{2}$ FDIGDP $+\omega_{1} I N F L+\omega_{4} P O P G+\omega_{5} E X C R+\omega_{6}$ TRPN $+\mu--$

Where $\omega_{0}$ is the constant term, and $\omega_{1}$ to $\omega_{50}$ are the parameters to be estimated. It is expected that $\omega_{1}>0, \omega_{2}>0, \omega_{12}<0, \omega_{4}<0, \omega_{5}<0$, and $\omega_{6}<0$ or $>0$.

\section{Measurement of Variables}

i. EDV is measured in its log form as the per capita GDP. This is obtained by dividing GDP by the total population. This actually measures how much of the total output goes to each of the individual in the society.

ii. FDIGDP is a proportion of foreign direct investment net inflows to GDP. It is obtained as foreign direct investment net inflows/GDP $\times 100$.

iii. BMGDP is measured by dividing the broad money supply by the GDP. This gives an index for measuring financial sector development in an economy.

iv. INFl is measured as the consumer price index. The captures the changes in the general price level in the economy.

v. POPG is a measure of the population growth of the country. It is calculated as: POPG $=$ New Population - old Population/old Population $\times 100$.

vi. EXCR is the rate at which the naira exchanges to a dollar. Thus, it is expressed as the $\# / \$$ rate in the economy.

vii. TRPN measures the rate of liberalization in the economy. It is measured by dividing total trade by GDP, and then multiplying through by 100 . $T R P N={ }^{\text {export }+ \text { import } / G D P} \times 100$. It captures the extent to which the economy is exposed to external markets. 


\section{Analytical Technique}

The study starts by first examining the time series properties of the variables before using an appropriate technique for the estimation. The diagnostic test so employed is the unit root test which examines the time series properties of the variables. Then, the 'ordinary least squares' method along with the 'autoregressive distributed lag' (ARDL) approach is examined to investigate both the short-run and long-term estimates of the parameters. The Granger causality test is also utilized to detect the nature of causal relationship between foreign direct investment and 'economic development' in Nigeria.

\section{RESULTS AND DISCUSSION}

In this section, we start by examining the descriptive properties of the variables and then, we proceed to examine the relationship between them through the use of correlation analysis. This is followed by the unit root test, bounds test for cointegration, the short-run and long-term estimates, and Granger causality test.

\section{Descriptive Statistics}

The descriptive statistics of the variables is presented in the table below.

Table 2. Descriptive Statistics of the Variables

\begin{tabular}{|l|c|c|c|c|c|c|c|}
\hline & LOGEDV & BMGDP & EXCR & FDIGDP & INFL & POPG & TRPN \\
\hline Mean & 7.477 & 16.053 & 68.810 & 1.671 & 18.415 & 2.602 & 33.101 \\
\hline Median & 7.490 & 13.399 & 21.886 & 1.608 & 12.876 & 2.586 & 34.457 \\
\hline Maximum & 7.849 & 28.625 & 306.083 & 5.790 & 72.835 & 3.031 & 53.277 \\
\hline Minimum & 7.188 & 9.063 & 0.546 & -1.150 & 3.457 & 2.285 & 9.135 \\
\hline Std. Dev. & 0.220 & 5.560 & 85.006 & 1.228 & 15.755 & 0.149 & 12.211 \\
\hline Skewness & 0.140 & 0.606 & 1.125 & 1.022 & 1.905 & 0.901 & -0.400 \\
\hline Kurtosis & 1.592 & 1.886 & 3.506 & 5.047 & 5.810 & 4.573 & 2.171 \\
\hline
\end{tabular}

Source: Author Computation

From Table 2, the log of EDV averaged 7.477, having a maximum value and minimum value of 7.849 and 7.188 respectively. The standard deviation of the variable is given to be 0.220 ; while the distribution is positively skewed, given the coefficient of skewness to be 0.140. The average value of BMGDP is given to be $16.053 \%$ and a standard deviation of $5.560 \%$. The maximum and minimum values of the variables are given to be $28.625 \%$ and $9.063 \%$ respectively; and the distribution is positively skewed as portrayed by the coefficient of skewness being 0.606. Other variables can be defined in similar manner. For example, FDIGDP averaged $1.671 \%$ with a standard deviation of 1.228 ; while its minimum and maximum value were $5.790 \%$ and $-1.150 \%$ respectively. Given the coefficient of skewness to be 1.022 , the distribution is skewed to the right.

\section{Correlation Analysis}

In detecting the nature of the bond amid the variables in the model, the correlation analysis is conducted. The result is portrayed in the correlation matrix below.

Table 3. Correlation Matrix

\begin{tabular}{|c|c|c|c|c|c|c|c|}
\hline & LOGEDV & BMGDP & EXCR & FDIGDP & INFL & POPG & TRPN \\
\hline LOGEDV & 1 & & & & & & \\
\hline BMGDP & 0.762 & 1 & & & & & \\
\hline EXCR & 0.595 & 0.537 & & & & & \\
\hline FDIGDP & -0.226 & -0.270 & -0.038 & 1 & & & \\
\hline INFL & -0.362 & -0.200 & -0.256 & 0.466 & 1 & & \\
\hline
\end{tabular}




\begin{tabular}{|c|c|c|c|c|c|c|c|}
\hline POPG & 0.426 & 0.635 & 0.023 & -0.423 & -0.065 & 1 & \\
\hline TRPN & 0.216 & 0.301 & 0.120 & 0.205 & -0.025 & 0.3029 & 1 \\
\hline
\end{tabular}

Source: Author Computation

From the correlation matrix showcased in Table 3, it is observed that logEDV has a strong positive relationship with BMGDP given the correlation coefficient of 0.762 . It follows that the two variables move in similar direction. Meanwhile, logEDV has a fairly strong positive relationship with EXCR given the correlation coefficient of 0.595. Thus, the two variables also move in the same direction. Population growth (POPG) and trade openness (TRPN) also has positive relationship with $\operatorname{logEDV}$, though such relationship is weak given the correlation coefficient of 0.426 and 0.216 respectively. Both FDIGDP and INFL has weak negative relationship with logEDV as captured by their respective correlation coefficient of -0.226 and -0.362 . This means that the two variables moves in the opposite direction with $\operatorname{logEDV}$. A look at the correlations between the explanatory variables showcases that none of the explanatory variables correlates perfectly with the other. Thus, multicollinerarity is ruled out. For example, the correlation between BMGDP and EXCR is positive (0.537); while that with INFL is negative $(-0.200)$.

\section{Unit Root Test}

The test for the stationarity of the time series variables us conducted using the augmented Dickey-Fuller (ADF) unit root test and the Elliot-Rothenberge-Stock-Point Optimal (ERS) test. The result is summarized below.

Table 4. Unit Root Test Result

\begin{tabular}{|c|c|c|c|c|c|c|}
\hline \multicolumn{2}{|l|}{ Augmented Dickey-Fuller Test (ADF) } & \multicolumn{3}{|c|}{$\begin{array}{c}\text { Elliott-Rothenberg-Stock Point- } \\
\text { Optimal (ERS) }\end{array}$} \\
\hline Variables & Level & $\begin{array}{c}\text { First } \\
\text { Difference }\end{array}$ & $\begin{array}{c}\text { Order of } \\
\text { Integration }\end{array}$ & Level & $\begin{array}{c}\text { First } \\
\text { Difference }\end{array}$ & $\begin{array}{c}\text { Order of } \\
\text { Integration }\end{array}$ \\
\hline LOGEDV & -0.7979 & $-3.4514^{* *}$ & $\mathrm{I}(1)$ & 8.8688 & $1.0147^{* * *}$ & $\mathrm{I}(1)$ \\
\hline BMGDP & -2.1329 & $-7.1319^{* * *}$ & $\mathrm{I}(1)$ & 4.9318 & $1.0704 * * *$ & $\mathrm{I}(1)$ \\
\hline FDIGDP & $-3.5897^{* *}$ & ------- & $\mathrm{I}(0)$ & $1.4846^{* *}$ & ------ & $\mathrm{I}(0)$ \\
\hline INFL & $-3.4146^{* *}$ & ------ & $\mathrm{I}(0)$ & $1.5923^{* *}$ & ------ & $\mathrm{I}(0)$ \\
\hline POPG & $-4.2475^{* *}$ & ------- & $\mathrm{I}(0)$ & 3.91000 & $1.1974^{* * *}$ & $\mathrm{I}(1)$ \\
\hline EXCR & 2.4792 & $-4.6614^{* * *}$ & $\mathrm{I}(1)$ & 78.7405 & $1.2308^{* * *}$ & $\mathrm{I}(1)$ \\
\hline TRPN & $-2.7306^{*}$ & $-7.8983^{* * *}$ & $\mathrm{I}(1)$ & $3.4560^{*}$ & $1.1896^{* * *}$ & $\mathrm{I}(1)$ \\
\hline
\end{tabular}

Source: Author Computation

To summarize the unit root test, Table 4 shows the order in which the variables are integrated. From the result, both the ADF and ERS test indicated that FDIGDP and INFL are stationary at level. Hence, they are $\mathrm{I}(0)$ variables. However, ADF test reported that POPG is stationary at level while the ERS test reported that the same variable is stationary at first difference. Since the ERS test is claimed to be more powerful than the ADF test, we conclude that POPG is stationary at first difference, and hence, it is an I(1) variable. All other variables are reported to be stationary at first difference by both the ADF test and the ERS test. A summary of The unit root test shows that the variable is stationary at both the level and the first difference. Therefore, check the long-term relationships between variables through use of the Bounds test for cointegration.

\section{Test for Cointegration}

The test for cointegration is conducted using the Bounds test for levels relationship. The test utilizes the F-statistic to check for the existence of the long-term relationship. The outcome of the test is presented below. 
Table 5. Bounds Test for Cointegration

\begin{tabular}{|l|c|c|c|c|}
\hline Test Statistic & Value & Significance & $\mathbf{I}(\mathbf{0})$ & $\mathbf{I}(\mathbf{1})$ \\
\hline F-statistic & 4.847274 & $10 \%$ & 1.99 & 2.94 \\
\hline $\mathrm{k}$ & 6 & $5 \%$ & 2.27 & 3.28 \\
\hline & & $1 \%$ & 2.88 & 3.99 \\
\hline
\end{tabular}

Source: Author Computation

From the result presented in Table 5, the F-statistic (4.8473) is outside the lower and upper bounds critical value. Since it is outside the $\mathrm{I}(0)$ and $\mathrm{I}(1)$ critical bounds value, the null hypothesis of no levels relationship is overruled at the $5 \%$ level. Therefore, there is a long-term bond among the variables, hence, cointegration exists. We therefore proceed to examine the short-run and long-term estimates.

\section{Short-Run ARDL Error Correction Mechanism}

In this sub-section, the outcome of the estimated ECM model is presented to portray how the short-run imbalance is rectified so that equilibrium is reinstated in the long-term. The result is presented as follows.

Table 6. Error Correction Mechanism

\begin{tabular}{|c|c|c|c|c|}
\hline \multicolumn{5}{|c|}{$\begin{array}{l}\text { Dependent Variable: D(LOGEDV) } \\
\text { Selected Model: ARDL }(1,0,2,1,2,2,0)\end{array}$} \\
\hline Variable & Coefficient & Standard Error & t-Statistic & Probability \\
\hline $\mathrm{D}(\mathrm{EXCR})$ & -0.000561 & 0.000323 & -1.735375 & $0.0923 *$ \\
\hline $\mathrm{D}(\mathrm{EXCR}(-1))$ & -0.000872 & 0.000357 & -2.443030 & $0.0203 * *$ \\
\hline D(FDIGDP) & -0.016295 & 0.004790 & -3.401503 & $0.0018 * * *$ \\
\hline $\mathrm{D}$ (INFL) & -0.001217 & 0.000353 & -3.444363 & $0.0016^{* * * *}$ \\
\hline $\mathrm{D}(\mathrm{INFL}(-1))$ & 0.001414 & 0.000401 & 3.530151 & $0.0013 * * *$ \\
\hline $\mathrm{D}(\mathrm{POPG})$ & -0.505474 & 0.203369 & -2.485509 & $0.0184 * *$ \\
\hline $\mathrm{D}(\mathrm{POPG}(-1))$ & 0.780985 & 0.195511 & 3.994590 & $0.0004 * * *$ \\
\hline CointEq(-1)* & -0.146208 & 0.021268 & -6.874658 & $0.0000 * * *$ \\
\hline \multicolumn{2}{|l|}{ R-squared } & \multicolumn{2}{|c|}{ Log Likelihood } & 97.170 \\
\hline Adjusted R-squared & 0.6281 & \multicolumn{2}{|c|}{ Durbin-Watson stat } & 2.119 \\
\hline
\end{tabular}

Source: Author Computation

The short-run estimates, as presented in Table 6, indicates Foreign direct investment has had an undesired and significant impact on Nigeria's economic development in the short term. Therefore, on average, the increase in the proportion of net foreign direct investment inflows is to a $1.63 \%$ increase in 'economic development'. Exchange rate is detected to wield a deleterious but insignificant effect on $\log \mathrm{EDV}$ at the 5\% significance level. Meanwhile, its one-period lag wields a deleterious and substantial effect at the 5\% critical level. Thus, the previous period's exchange rate reduces $\operatorname{logEDV}$ by $0.09 \%$. Similarly, inflation and its one-period lag generated a deleterious and substantial influence on $\log \mathrm{EDV}$ at the $5 \%$ critical level. Thus, a unit percentage increase in INFL reduces logEDV by $0.12 \%$, while its previous value reduces $\log$ EDV by $0.14 \%$. Population growth (POPG) is detected to have a deleterious and substantial influence on $\operatorname{logEDV}$; while its one-period lag breeds a positive and substantial effect. Thus, a unit percentage increase in POPG will cause $\log$ EDV to reduce by $50.54 \%$; while the previous period POPG increase logEDV by $78.10 \%$. This points out the fact that population explosion is harmful to the development potential of the Nigerian society.

The error correction mechanism $(-0.1462)$ is negative and significant at the $1 \%$ significance level. The implication of the ECM is that $14.62 \%$ of the short-run imbalance is rectified yearly so that equilibrium is reinstated in the long-term. The r-squared (0.6846) is an indication that $68.46 \%$ of the total variations in logEDV in the short-run is explained by 
changes in the explanatory variables. The Durbin-Watson statistic of 2.119 rules out the problem of serial correlation in the model.

\section{Levels Equation: Restricted Constant and No Trend}

The long-term result of the ARDL estimates is presented as follows.

Table 7. Long-term Estimates

\begin{tabular}{|c|c|c|c|c|}
\hline \multicolumn{5}{|l|}{ Dependent Variable: LOGEDV } \\
\hline Variable & Coefficient & Standard Error & t-Statistic & Probability \\
\hline BMGDP & 0.022157 & 0.006250 & 3.544927 & $0.0010^{* *}$ \\
\hline FDIGDP & 0.015769 & 0.022598 & 0.697794 & 0.4892 \\
\hline INFL & -0.003132 & 0.001523 & -2.056988 & $0.0459^{* *}$ \\
\hline POPG & 0.146502 & 0.219419 & 0.667679 & 0.5080 \\
\hline EXCR & 0.000631 & 0.000319 & 1.979617 & $0.0543^{*}$ \\
\hline TRPN & -0.000627 & 0.001897 & -0.330510 & 0.7427 \\
\hline C & 6.748990 & 0.512916 & 13.15808 & $0.0000^{* * *}$ \\
\hline R-squared & 0.6668 & Durbin-Watson statistic & 1.782 \\
\hline F-statistic & 14.012 & Prob(F-statistic) & 0.0000 \\
\hline
\end{tabular}

Source: Author Computation

Comparing the short-run estimates in Table 7 with the long-term estimates in Table 4.6, we can see that FDIGDP now generate a positive, though insignificant, effect on logEDV at 5\% level. This calls for concern on the potency of FDI in promoting development of the Nigerian economy. In the same manner, inflation still wields a deleterious and substantial influence on $\operatorname{logEDv}$ in the long-term at the 5\% level. It follows that a unit percentage increase in inflation will reduce $\operatorname{logEDV}$ by $0.31 \%$ in the long-term. Also, population growth and exchange rate exert a positive and insignificant effect on $\operatorname{logEDV}$ at the 5\% level in the long-term. It is observed that BMGDP generates a positive and significant effect on $\log \mathrm{EDV}$ at the $5 \%$ level. It follows from the coefficient that a unit percentage increase in BMGDP will lead to a $2.22 \%$ in the long-term. This points out the potency of the financial sector in stimulating development in Nigeria. As put forward by Alfaro et al. (2009), nations with strong financial system are most likely to benefit to a large extent from FDI. Conversely, TRPN generates a negative and insignificant long-term effect on $\log \mathrm{EDV}$.

\section{Granger Causality Test}

The Granger causality test is conducted to ascertain the effect of net foreign direct investment inflows on 'economic development' of Nigeria. The result is presented below.

Table 8. Granger Causality Test Result

\begin{tabular}{|l|c|c|c|}
\hline Null Hypothesis & Observations & F-statistic & Probability \\
\hline FDIGDP does not Granger Cause EDV & 48 & 6.69365 & $0.0130^{* *}$ \\
EDV does not Granger Cause FDIGDP & & 1.75873 & 0.1915 \\
\hline
\end{tabular}

Source: Author Computation

The Granger causality test result in Table 8 indicates that FGIGDP Granger causes EDV since the F-statistic (6.69365) is significant at the 5\% level, given the p-value if 0.0130. Therefore, the null hypothesis that FDIGDP does not Granger cause EDV is rejected. However, EDV does not Granger cause FDIGDP since the F-statistic (1.75873) is not statistically significant at the $5 \%$ level, given the p-value of 0.1915 . Thus, the null hypothesis that EDV does not Granger cause FDIGDP is accepted. This indicates that there 
is a unidirectional causality flowing from FDIGDP to EDV. This validates the 'FDI-led growth hypothesis' within the Nigeria context.

\section{CONCLUSION}

The inflow of foreign direct investment is an indication that the investment gap of the domestic economy has been filled. As such, the gap-filling role is expected to yield some core benefits to the domestic economy. This can be viewed in the form of employment generation, poverty reduction, economic growth, and overall development of the domestic economy. Such expectations can only be attained if the necessary environment is created for foreign investors to thrive. Such can be in the form of stability in the political realm, peaceful and terrorism free society, and effective governance. This study therefore delved into ascertaining if the foreign direct investment led growth hypothesis is valid in Nigeria. It is in this light that the study utilized the ARDL approach to ascertain both the short-run and the long-term effect of FDI inflow on 'economic development' of Nigeria from 1970 2018. The result revealed that foreign direct investment generated a negative and significant short-run effect on the 'economic development' of Nigeria; while the long-term result portrayed a positive but insignificant effect. This can be linked to the repatriation of profit rather further investment in the domestic economy to foster progress. The study further revealed that financial development is potent in promoting 'economic development in Nigeria; while inflation and population growth are limiting factors. The Granger causality test revealed that a one-way causality flows from net foreign direct investment inflow to 'economic development'. This validates the 'FDI-led growth hypothesis' within the Nigeria context.

In the light of the above, the paper offered the following recommendations:

i. There is need for the removal of bottlenecks that may impound FDI influx in Nigeria. Issues of poor infrastructures and over regulation should be duly addressed. Meanwhile, such should be geared towards the long-term. but in the short-run, improved domestic production should be stimulated to propel growth rather than relying on inflow of foreign capital.

ii. There is need to restrict excessive repatriation of profits by multinationals. Policies should be made towards ensuring that a greater percentage of their profits are reinvested within the Nigerian economy.

iii. Since trade openness is seen to act as a deterrent to development in Nigeria, there is need for sound policies that will be geared towards guided liberalization of trade in the country.

iv. Sound financial development within the Nigerian economy is needed so as to promote local access to capital that can be utilized for domestic investments. In this way, local production will be stirred and development will accelerate.

\section{REFERENCES}

Abdallah, Z. T. and Abdullahi, A. (2013). Relationship between foreign direct investment and per capita GDP in Nigeria: An empirical analysis (1980-2009). International Journal of Business, Humanities and Technology, 3, 152-158.

Aitken, B., and Harrison, A. (1999). Do domestic firms benefit from direct foreign investment? Evidence from Venezuela. The American Economic Review, 89(3), 605618. doi:10.1257/aer.89.3.605

Akinboade, O. A., Siebrits, F. K. and Roussot, E. N. (2006). Foreign direct investment in South Africa. In: Ajayi (Ed.), Foreign Direct Investment in Sub-Saharan Africa- 
Origin, Targets, Impact and Potential. African Economic Research Consortium, Nairobi.

Akinlo, A. E. (2004). Foreign direct investment and growth in Nigeria - An empirical investigation. Journal of Policy Modelling, 26, 627-639.

Alfaro, L., Kalemli-Ozcan, S., and Sayek, S. (2009). FDI, productivity and financial development. World Economy, 32(1), 111-135. doi: 10.1111/twec.2009.32.issue-1

Alshamsi, K. H., Rasid bin Hussin, M. and Azam, M. (2015). The impact of inflation and GDP per capita on foreign direct investment: The case of United Arab Emirates. Investment Management and Financial Innovation, 12, 132-141.

Aminu, K. (2020). Impact of foreign direct investment on economic growth in Nigeria. Department of Department of Economics, Faculty of Management and Social Sciences, Baze University, Abuja.

Anarfo, E. B., Agoba, A. M. and Abebreseh, R. (2017). Foreign direct investment in Ghana: The role of infrastructural development and natural resources. African Development Review, 29(4), 575-588.

Ang, J. B. (2009). Financial development and the FDI growth nexus: The Malaysian experience. Applied Economics, 41(13), 1595-1601. doi:10.1080/00036840701222553.

Arrow, K. (1962). Economic welfare and the allocation of resources for invention. Princeton University Press, 609 - 626.

Asamoah, M. F., Adjasi, C. K. D. and Alhassan, A. L. (2016). Macroeconomics uncertainty, foreign direct investment and institutional quality: Evidence from SubSaharan Africa. Economic System, 40, 612-621.

Bitzer, J., and Gorg, H. (2009). Foreign direct investment, competition and industry performance. World Economy, 32(2), 221-233. doi: 10.1111/twec.2009.32.issue-2

Blomstrom, M., and Kokko, A. (1998). Multinational corporations and spill overs. Journal of Economic Surveys, 12, 247-277. doi:10.1111/1467-6419.00056

Carbonell, J. B. and Werner, R. A. (2018). Does foreign direct investment generate economic growth? a new empirical approach applied to Spain. Economic Geography, 94, 425-456.

Chan, M. W. L., Hou, K., Li, X. and Mountain, D. C. (2014). Foreign direct investment and its determinants: A regional panel causality analysis. Quantitative Review of Economics and Finance, 54, 579 - 589.

De Mello, L. (1999). Foreign direct investment-led growth: Evidence from time series and panel data. Oxford Economic Papers, 51, 133 - 151. doi:10.1093/oep/51.1.133

Dutta, N. and Roy, S. (2011). Foreign direct investment, financial development and political risks. Journal of Development Areas, 44, 303-327.

Fosfuri, A., Motta, M., and Ronde, T. (2001). Foreign direct investment and spill overs through workers' mobility. Journal of International Economics, 53(1), 205-222. doi:10.1016/S0022-1996(00)00069-6.

Gherghina, S. G., Simionescu, L. N. and Hudea, O. S. (2019). Exploring foreign direct investment-economic growth nexus - Empirical evidence from central and eastern European countries. Sustainability, 11, 5421. doi:10.3390/su11195421

Giwa, B. A., George, E. O., Okodua, H. and Adediran, O. S. (2020) Empirical analysis of the effects of foreign direct investment inflows on Nigerian real economic growth: Implications for sustainable development goal-17. Cogent Social Sciences, 6(1), 1727621. https://doi.org/10.1080/23311886.2020.1727621

Glass, A., and Saggi, K. (2002). Multinational firms and technology transfer. The Scandinavian Journal of Economics, 104(4), $495-513$. doi: 10.1111/sjoe.2002.104.issue-4. 
Grossman, G. M., and Helpman, E. (1991). Trade, knowledge spill overs and growth. European Economic Review, 35, 517-526. doi:10.1016/0014-2921(91)90153-A

Haddad, M. and Harrison, A. (1993). Are there positive spill overs from direct foreign investment? Evidence from panel data for Morocco. Journal of Development Economics, 42 (1), 51-74. doi:10.1016/0304-3878(93)90072-U.

Herzer, D. and Klasen, S.; Nowak-Lehmann, F. (2008). In search of FDI-led growth in developing countries: The way forward. Economic Modelling, 25, 793-810.

Hymer, S. (1976). (1960). The International operations of nation firms: A study of foreign direct investment. Cambridge: MLT Press.

Iamsiraroj, S. and Doucouliagos, H. (2015). Does growth attract FDI? Economics, 9, 1-35.

Jenkins, S. (1990). The distribution of wealth: Measurement and models. Journal of Economic Surveys, 4(4), 329 - 360. doi: 10.1111/joes.1990.4.issue-4.

Joshua, U. (2019). An ARDL approach to the government expenditure and economic growth nexus in Nigeria. Academic Journal of Economic Studies, 5(3), 152-160.

Joshua, U. and Alola, A. A. (2020). Accounting for environmental sustainability from coalled growth in South Africa: The role of employment and FDI. Environmental Science and Pollution Control Series, 1-11.

Joshua, U., Adedoyin, F. F. and Sarkodie, S. A. (2020). Examining the external-factors-led growth hypothesis for the South African economy. Heliyon 6, e04009.

Joshua, U., Bekun, F. V. and Sarkodie, S. A. (2020). New insight into the causal linkage between economic expansion, FDI, coal consumption, pollutant emissions and urbanization in South Africa. Environmental Science and Pollution Control Series, 1-12.

Ketteni, E.; Kottaridi, C. (2019). The impact of regulations on the FDI-growth nexus within the institution-based view: A nonlinear specification with varying coefficients. International Business Review, 28, 415 - 427.

Khobai, H., Hamman, N., Mkhombo, T., Mhaka, S., Mavikela, N. and Phiri, A. (2017). The FDI growth nexus in South Africa: A re-examination using quantile regression approach. MPRA Paper No. 80152. https://mpra.ub.uni-muenchen.de/80152/

Kinuthia, B. K. and Murshed, S. M. (2015). FDI determinants: Kenya and Malaysia compared. Journal of Policy Modelling, 37, 388 - 400.

Kokko, A. (1996). Productivity spill overs from competition between local firms and foreign affiliates. Journal of International Development, 8, 517 - 530.

Kottaridi, C. and Stengos, T. (2010). Foreign direct investment, human capital and nonlinearity in economic growth. Journal of Macroeconomics, 32, $858-871$.

Leitão, N. C. and Rasekhi, S. (2013). The impact of foreign direct investment on economic growth: The Portuguese experience. Theoretical and Applied Economics, 20, 51-62.

Lucas, R. E. B. (1988). On the mechanism of economics development. Journal of Monetary Economics, 22, 3 - 42. doi:10.1016/0304-3932(88)90168-7.

Mahadika, I. N., Kalayci, S. and Altun, N. (2017). Relationship between GDP, Foreign Direct Investment and Export Volume: Evidence from Indonesia. International Journal of Trade, Economics and Finance, 8, 51-54.

Mahapatra, R. and Patra, S. (2014). Impact of foreign direct investment (FDI) inflow on gross domestic product (GDP) of India - An empirical study. International Journal of Business Management Invention, 3, 12-20.

Malikane, C., and Chitambara, P. (2017). Foreign direct investment, democracy and economic growth in Southern Africa. Africa Development Review, 29(1), 92-102. doi:10.1111/1467-8268.12242 
Ndiaye, G. and $\mathrm{Xu}, \mathrm{H}$. (2016). Impact of foreign direct investment (FDI) on economic growth in WAEMU from 1990 to 2012. International Journal of Finance Research, 7, 33-43.

Olorogun, L. A., Salami, M. A. and Bekun, F. V. (2020). Revisiting the Nexus between FDI, financial development and economic growth: Empirical evidence from Nigeria. Journal of Public Affairs, e2561.

Olorogun, L. A. (2021). Revisiting the nexus of FDI- led growth hypothesis and economic development in Rwanda: A Johansen- ARDL approach to cointegration. Journal of the Knowledge Economy, Springer. https://doi.org/10.1007/s13132-021-00822-w

Olorogun, L. A. (2021). The nexus between FDI inflows and economic development in Ghana: Empirical analysis from ARDL model. Journal of Global Business Advancement, 14(1), 93-114.

Papageorgiadis, N., McDonald, F., Wang, C. and Konara, P. (2020). The characteristics of intellectual property rights regimes: How formal and informal institutions affect outward FDI location. International Business Review, 29, 101620.

Rani, R., and Kumar, N. (2019). On the causal dynamics between economic growth, trade openness and gross capital formation: Evidence from BRICS countries. Global Business Review, 20(3), $795-812$.

Romer, P. (1986). Increasing returns and long-term growth. The Journal of Political Economy, 94(5), 1002-1037. doi:10.1086/261420.

Roy, S. (2009). Foreign direct investment and total factor productivity growth: Does distance from technology frontier matter. doi: 10.2139/ssrn.1424690 Available at: https://ssrn.com/abstract $=1424690$

Saini, A., Madan, P. and Batra, S. K. (2015). Impact of FDI inflow on economic growth of SAARC economies. International Journal of Engineering, Business and Entrepreneurial Application, 12, 161-166.

Sarkodie, S. A. and Adams, S. (2018). Renewable energy, nuclear energy, and environmental pollution: Accounting for political institutional quality in South Africa. Science of the Total Environment, 643, 1590-1601.

Schmitt, D. and Alexiou, C. (2016). On the FDI-led growth hypothesis: Empirical evidence from Ireland. The Empirical Economics Letters, 15(2), 135 - 144.

Schneider, P. H. (2005). International trade, economic growth and intellectual property rights: A panel data study of developed and developing countries. Journal of Development Economics, 78, 529-547.

Senbeta, S. (2008). The nexus between FDI and total factor productivity growth in SubSaharan Africa. Germany: MPRA Paper from University Library of Munich.

Solow, R. M. (1956). A contribution to the theory of economic growth. The Quarterly Journal of Economics, Oxford University Press, 70(1), 65 - 94. doi:10.2307/1884513

Sunde, T. (2017). Foreign direct investment, exports and economic growth: ADRL and causality analysis for South Africa. Research International Journal of Business and Finance, 41, $434-444$.

Temiz, D. and Gokmen, A. (2014). FDI inflow as an international business operation by MNCs and economic growth: An empirical study on Turkey. International Business Review, 23, 145-154.

Udi, J., Bekun, F. V. and Adedoyin, F. F. (2020). Modelling the nexus between coal consumption, FDI inflow and economic expansion: does industrialization matter in South Africa? Environmental Science and Pollution Research, 1-12.

UNCTAD, (2018). United Nations Conference on Trade and Development. World Investment Report. https://unctad.org/en/PublicationsLibrary/wir2018_en.pdf 
Wang, J., and Blomstrom, M. (1992). Foreign investment and technology transfer: A Simple model. European Economic Review, 36(1), 137-155. doi: 10.1016/00142921(92)90021-N

World Development Indicators (2019). World Bank.

World Governance Indicators (2019). World Bank.

Woo, J. (2009). Productivity growth and technology diffusion through foreign direct investment economic inquiry. Western Economic Association International, 47(2), 226-248.

Yalta, A. Y. (2013). Revisiting the FDI-led growth Hypothesis: The case of China. Economic Modelling, 31, 335-343.

Zandile, Z. and Phiri, A. (2019). FDI as a contributing factor to economic growth in Burkina Faso: How true is this? Global Economy Journal, 19(01), 1950004. 